\title{
PEMBELAJARAN EFEKTIF BAHASA INGGRIS MELALUI LAGU ANAK- ANAK UNTUK SISWA MADRASAH IBTIDAIYAH (MI)
}

\author{
en $\infty$ \\ Dina Novita Wijayanti \\ Universitas Muria Kudus, Jawa Tengah, Indonesia \\ ou-co
}

\begin{abstract}
EFFECTIVE ENGLISH LEARNING THROUGH KIDS SONG FOR ISLAMIC ELEMENTARY SCHOOL STUDENTS: An English teacher is demanded to be creative in creating a learning process that is easy and fun especially for Islamic elementary school students. One of the learning strategies used by the teacher is the use of songs. The purpose of this study was to determine examples of children's songs that effectively, gains the use of a children's song and effective measures to learning English for students of Government Elementary School. This study used a qualitative approach, especially literature research. The results of the study showed that there are 20 examples of effective children's songs for learning English. The use of children's songs for learning English showed that songs can increase the enthusiasm of children to learn English because learning is fun and does not feel stiff while steps are taken to create learning English is an effective English teachers should consider some aspects, types of songs, number of students, the type of learning activities with the song, and the character of the students.
\end{abstract}

Key words: effective learning, English, children's songs, Islamic Elementary School students

\section{A. Pendahuluan}

Di era globalisasi seperti sekarang ini, kita tidak hanya dituntut untuk melek teknologi tetapi juga harus memiliki kecakapan lain yang mendukung. Salah satunya adalah ketrampilan berkomunikasi aktif dengan bahasa Inggris. Seperti yang kita ketahui bahasa Inggris adalah bahasa internasional yang digunakan sebagai alat komunikasi antar negara. Begitu pentingnya peranan bahasa Inggris dalam dunia Internasional maka Bahasa Inggris dimasukkan 


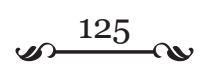

dalam salah satu mata pelajaran yang diajarkan di setiap lembaga-lembaga pendidikan formal mulai dari tingkat sekolah dasar sampai perguruan tinggi di Indonesia.

Dalam pelaksanaannya, ada beberapa kendala yang ditemui seperti para siswa kesulitan dalam memahami mata pelajaran bahasa asing ini. Hal ini cukup beralasan mengingat posisi bahasa Inggris di Indonesia adalah sebagai bahasa asing. Pengertian bahasa asing adalah bahasa yang tidak digunakan untuk berkomunikasi sehari-hari melainkan aktif digunakan dalam kelas saja ketika proses belajar dan mengajar berlangsung. Hal ini sesuai dengan pernyataan dari peneliti yang menyatakan tentang pengertian bahasa asing yakni bahasa yang yang tidak digunakan sebagai alat komunikasi di negara tertentu di mana bahasa tersebut diajarkan (Miranti, Engliana, dan Hapsari, 2015: 167).

Untuk mengatasi kendala tersebut, maka diperlukan teknik pembelajaran yang efektif, tepat, dan menarik sehingga para peserta didik termotivasi untuk belajar bahasa asing ini. Pembelajaran efektif adalah suatu pembelajaran yang memungkinkan peserta didik untuk dapat belajar dengan mudah, menyenangkan, dan dapat tercapai tujuan pembelajaran yang telah ditetapkan (HR, 2015: 6). Untuk itu, guru dituntut mampu menciptakan suasana belajar yang tidak biasa. Dengan kata lain, proses pembelajaran tidak hanya diartikan seperti guru mengajarkan suatu materi kepada para siswa sedangkan para siswa mendengarkan penjelasan dari guru melainkan seorang guru harus menciptakan suasana belajar mengajar yang hidup (peserta didik aktif mengikuti kegiatan belajar mengajar dengan situasi yang menyenangkan). Untuk menciptakan suasana kelas Bahasa Inggris yang menyenangkan, salah satunya adalah dengan penggunaan lagu untuk media pembelajaran.

Dalam rangka penggunaan lagu untuk media pembelajaran, seorang guru harus jeli dalam memilih jenis lagu, tingkat kemudahan lagu, makna lagu, dan sasaran tingkat dan karakter peserta didik. Hal ini diperlukan sebab penggunaan lagu yang tidak sesuai dan tanpa melihat sasaran (level peserta didik), akan terasa kurang bermanfaat. Hal ini dikarenakan tidak tercapainya tujuan pembelajaran yang diinginkan. Dalam hal ini sasaran peserta didik yang akan diajari bahasa Inggris adalah peserta didik level sekolah dasar (Madrasah Ibtidaiyah). Siswa madrasah ibtidaiyah adalah siswa dengan jenjang setara dengan siswa SD. Perbedaan siswa MI dan SD 
adalah mata pelajaran yang diberikan ke siswa madrasah ibtidaiyah tidak hanya pelajaran umum tetapi beberapa mata pelajaran agama. Hal ini dirasa perlu untuk mengajarkan bahasa Inggris sejak dini karena belajar bahasa di tingkat dasar cenderung efektif dilakukan mengingat anak-anak berada dalam masa keemasan sehingga mereka lebih mahir dalam menyerap hal-hal baru termasuk belajar bahasa Inggris.

Demi kebutuhan pengajaran bahasa Inggris untuk anak tingkat sekolah dasar (MI) hendaknya seorang guru bahasa Inggris melakukan pemilihan lagu yang tepat. Sebelum menggunakan lagu sebagai media pengajaran untuk anak SD hendaknya guru memilih lagu yang sederhana dan sesuai dengan kebutuhan belajar. Pilih pula lagu yang liriknya bisa terdengar jelas, juga pelafalan (pronunciation) yang benar. Ada banyak lagu Bahasa Inggris untuk anak-anak sekolah dasar yang bisa digunakan sebagai media pembelajaran diantaranya adalah $A B C$, Ten Little Fingers, Ten Little Indians, Old Mc Donald, Bingo, That is, Days of the Week, Moths, I have A Cock, Wheel on the Bus, The Bear Went Over the Mountain, Can You Touch Your Toes, London Bridge, Head and Shoulders, Twinkle Twinkle Little Stars, Bluebird, Are You Sleeping, If you are happy?, A hundred Miles dsb.

Karena siswa akan menggunakan lagu Bahasa Inggris sebagai model maka tentu mereka harus menemukan model yang terbaik. Jika guru yang akan menyanyikannya, maka harus dipastikan pula bahwa sang guru tersebut akan memberi model yang baik bagi siswanya (Nurhayati, 2009: 65). Selain itu, mengajarkan bahasa Inggris kepada siswa SD berbeda dengan mengajarkan bahasa ini kepada remaja atau orang dewasa. Siswa SD memiliki keunikan dan karakteristik tesendiri yang sedikit banyak mempengaruhi suasana pembelajaran di dalam kelas.

Ada beberapa karakteristik umum anak-anak yang perlu diketahui oleh para pendidik sebelum melakukan proses pembelajaran diantaranya bahwa anak-anak perlu bergerak, bisa berkonsentrasi untuk masa yang pendek, belajar melalui pengalaman, belum begitu mampu mengontrol dan merencanakan kegiatannya, tidak takut melalukan kesalahan atau mengambil resiko, tidak begitu memperhatikan diri mereka sendiri ataupun tindakan mereka, memperhatikan makna bahasa dan memiliki pengalaman yang terbatas dalam kehidupannya (Ellis dalam Nurhayati, 2009: 4). Menyadari hal tersebut maka seorang guru Bahasa Inggris untuk siswa Madrasah Ibtidaiyah dituntut untuk jeli dan kreatif dalam menggunakan lagu bahasa 


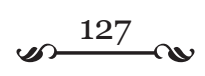

Inggris sebagai media pembelajaran.

Berdasarkan penjelasan di atas, maka tujuan penelitian yang berjudul "Pembelajaran Bahasa Inggris Efektif melalui Lagu Anak-Anak untuk Siswa Madrasah Ibtidaiyah" adalah memaparkan contoh lagu anak-anak yang efektif untuk pembelajaran Bahasa Inggris, keuntungan menggunakan lagu anak-anak untuk membantu pembelajaran bahasa Inggris pada siswa madrasah ibtidaiyah, serta bagaimana langkah-langkah yang efektif dalam menggunakan lagu-lagu tersebut dalam kelas bahasa Inggris untuk siswa madrasah ibtidaiyah. Penilitian ini membahas contoh lagu anak-anak, keuntungan penggunaan lagu anak-anak, dan langkah-langkah efektif dalam menggunakan lagu anak-anak untuk pembelajaran Bahasa Inggris bagi siswa Madrasah Ibtidaiyah.

Jenis penelitian ini adalah penelitan kepustakaan (library research), yaitu serangkaian penelitian yang berkenaan dengan metode pengumpulan data pustaka, atau penelitian yang obyek penelitiannya digali melalui beragam informasi kepustakaan (buku, ensiklopedi, jurnal ilmiah, koran, majalah, dan dokumen). Data yang digunakan dalam penelitian ini adalah data sekunder. Data sekunder merupakan data yang diperoleh bukan dari pengamatan langsung. Akan tetapi data tersebut diperoleh dari hasil penelitian yang telah dilakukan oleh peneliti-peneliti terdahulu. Sumber data sekunder yang digunakan dalam penelitian ini berupa 2 jurnal tentang penggunaan lagu Bahasa Inggris untuk siswa tingkat sekolah dasar dan PAUD. Jurnal yang dipilih penulis ada 2 yaitu "Penggunaan Lagu dalam Pembelajaran Bahasa Inggris untuk Siswa SD; Mengapa dan Bagaimana” oleh Lusi Nurhayati dan "Pembelajaran Bahasa Inggris melalui Lagu pada Anak Usia Dini” oleh Ida Vera Sophya.

Jurnal tersebut dipilih oleh penulis karena pertama, relevansi jurnal dengan rumusan masalah pada penelitian ini. Kedua, jurnal yang ditulis oleh Lusi Nurhayati tentang pembelajaran bahasa Inggris dengan lagu untuk siswa SD dipresentasikan dengan sukses 3x dengan judul yang mirip dalam jurnal yang berbeda. Dalam jurnal yang dibuat oleh Lusi, penulis mendapatkan banyak tambahan ilmu pengetahuan kepada para pembaca dan penulis baca khususnya tentang pentingnya penggunaan lagu -lagu Bahasa Inggris untuk anak SD, contoh lagu-lagu bahasa Inggris untuk anak-anak dan proses penggunaan lagu Bahasa inggris anak-anak untuk media pembelajaran. Selain itu, bahasan dalam jurnal yang berkaitan dengan lagu juga ditulis 


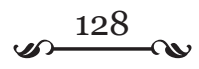

dengan runtut atau sistematis, lengkap, logis sehingga hasil penelitian yang dihasilkan juga valid.

Sedangkan jurnal yang kedua yang ditulis oleh Ida Vera Sophya (seorang dosen STAIN KUDUS) memaparkan tentang pentingnya lagu bahasa Inggris untuk anak-anak sebagai bahasa asing. Semua informasi tentang pentingnya lagu, proses penggunaan lagu untuk media anak-anak dalam belajar bahasa Inggris juga dipaparkan dengan tuntas dan teliti sehingga mendukung jurnal yang dibuat oleh Lusi. Hasil dari kedua jurnal tersebut tentang efektifnya penggunaan lagu Bahasa Inggris sebagai bahasa asing untuk anak-anak juga linier. Dengan kata lain, hasil penelitian mereka juga sama-sama menunjukkan bahwa penggunaan lagu bahasa Inggris sangat efektif sebagai media pembelajaran untuk anak-anak.

\section{B. Pembahasan}

\section{Kegiatan Pembelajaran di Kelas}

Proses kegiatan belajar mengajar berlangsung hampir setiap hari di kelas antara guru dan peserta didik. Dalam hal ini, proses tersebut umumnya dimaknai dengan guru mengajarkan suatu materi kepada para siswa sedangkan para siswa mendengarkan penjelasan dari guru. Untuk menjelaskan materi, guru bisa menggunakan buku atau sumber lain yang mendukung kegiatan belajar mengajar di kelas. Jika diperlukan, guru juga bisa memanfaatkan media pembelajaran yang ditemukan dari lingkungan sekitar seperti lagu, realia, video dsb. Singkatnya proses tersebut dinamakan proses KBM (Kegiatan Belajar Mengajar) atau proses pembelajaran di sekolah.

Pembelajaran adalah suatu situasi yang tercipta dari interaksi yang berlangsung antara berbagai faktor (multiple factor) ataupun komponen; guru, siswa (peserta didik), kurikulum, metode, sarana dan media serta komponen lainnya yang diperlukan (Yasin, 2012: 3).

Dari kutipan diatas, dapat ditarik kesimpulan bahwa suatu pembelajaran di dalam kelas bisa terjadi apabila tercipta suatu interaksi atau sinergi dari berbagai faktor yang mendukung proses KBM seperti adanya guru, para peserta didik, kurikulum, metode atau teknik mengajar, media mengajar dan lain-lain. Hal ini didukung pula dengan pendapat 
dari seorang ahli yang menyatakan bahwa

Pembelajaran di kelas adalah bantuan yang diberikan pendidik agar dapat terjadi proses pemerolehan ilmu dan pengetahuan, penguasaan kemahiran dan tabiat, serta pembentukan sikap dan kepercayaan pada peserta didik. Dengan kata lain pembelajaran adalah proses untuk membantu peserta didik kearah yang lebih baik (Mulyanah, 2014: 15).

Dalam hal ini, suatu kegiatan pembelajaran dilaksanakan untuk mencapai tujuan pembelajaran. Pencapaian tujuan pembelajaran secara optimal merujuk kepada suatu keadaan yang ditandai oleh tercapainya secara maksimal indikator-indikator pembelajaran (Suyono, 2009: 203). Untuk mencapai secara maksimal indikator-indikator pembelajaran yang diinginkan, seorang guru harus membuat rencana pelaksanaan pembelajaran (RPP) terlebih dahulu. Hal ini dilakukan supaya kegiatan pembelajaran bisa berjalan secara sistematis dan diharapkan bisa mencapai tujuan pembelajaran yang diinginkan.

Dalam hal ini, suatu kegiatan pembelajaran yang efektif bisa dikondisikan dengan suasana belajar yang menyenangkan sehingga kegiatan belajar mengajar tidak terasa kaku dan membosankan dan para siswa tidak jenuh selama kegiatan tersebut berlangsung. Proses belajar dimaknai sebagai proses dimana peserta didik mengaitkan pengalaman yang telah dimilikinya dengan pengalaman baru yang ditemukannya (HB, 2013: 280). Oleh karena itu, dalam rangka membantu peserta didik untuk mengaitkan pengalaman yang telah dimilikinya dengan pengalaman baru yang ditemukannya, seorang guru diharapkan bisa menciptakan suasana belajar yang menyenangkan. Hal itu merupakan kebutuhan setiap peserta didik, karena dengan suasana yang menyenangkan dalam belajar setiap peserta didik dapat berkespresi secara optimal.

Oleh karena itu, untuk mengoptimalkan suasana belajar yang menyenangkan bagi peserta didik, seorang guru bisa memanfaatkan berbagai media pembelajaran yang mendukung seperti foto, gambar, realia, video, dan lagu. Selain itu, selama proses kegiatan belajar berlangsung guru juga bisa menggunakan gerakan-gerakan yang menarik perhatian peserta didik dan bersikap ramah terhadap para murid sehingga terjadi proses pembelajaran yang menyenangkan dan diharapkan dapat mencapai tujuan-tujuan pembelajaran yang maksimal. 


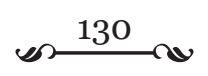

\section{Kegiatan Pembelajaran yang Efektif}

Kegiatan pembelajaran dimaknai sebagai proses dimana terjadi suatu interaksi atau sinergi dari berbagai faktor yang mendukung proses kegiatan belajar dan mengajar seperti adanya guru, para peserta didik, kurikulum, metode atau teknik mengajar, media mengajar dan lainlain. Dari adanya interaksi atau sinergi dari berbagai faktor tersebut diharapkan dapat mencapai kegiatan pembelajaran yang efektif. Dalam hal ini kata "efektif" diartikan sebagai sesuatu kegiatan yang sistematis, program terencana, efektif waktu dan dikerjakan secara kontinyu sehingga tercapai hasil yang baik (Mulyanah, 2014: 7). Dengan kata lain, "kegiatan pembelajaran yang efektif" adalah suatu kegiatan yang dirancang oleh guru secara sistematis, terencana dan berlangsung terus menerus demi tercapainya tujuan pembelajaran yang optimal sesuai dengan waktu yang tersedia.

Demi mencapai tujuan pembelajaran yang optimal hendaknya fokus pembelajaran dipusatkan pada student centered. Dengan kata lain, terjadinya_proses belajar pada peserta didik dan apa yang dilakukan oleh pendidik untuk membelajarkan peserta didiknya. Selain itu yang perlu diperhatikan adalah hendaknya pembelajaran efektif yang diterapkan bisa memotivasi para siswa untuk belajar atas kemauannya sendiri dengan cara mengaplikasikan pola pembelajaran yang menyenangkan. Hal ini senada dengan pendapat seorang ahli yang mengatakan bahwa pembelajaran efektif adalah suatu pembelajaran yang memungkinkan peserta didik untuk dapat belajar dengan mudah, menyenangkan, dan dapat tercapai tujuan pembelajaran yang telah ditetapkan (HR, 2015: 6).

Pola pembelajaran yang menyenangkan ini bisa dilakukan dengan memanfaatkan berbagai media pembelajaran yang mendukung seperti foto, gambar, realia, video, dan lagu. Selain itu, selama proses kegiatan belajar berlangsung guru juga bisa menggunakan gerakan-gerakan yang menarik perhatian peserta didik dan bersikap ramah terhadap para murid sehingga terjadi proses pembelajaran yang menyenangkan dan diharapkan dapat mencapai tujuan-tujuan pembelajaran yang maksimal dengan menerapkan 7 indikator pembelajaran efektif yaitu pengorganisasian materi dengan baik, komunikasi yang efektif, penguasaan dan antusiasme terhadap materi pelajaran, sikap positif terhadap peserta didik, pemberian nilai yang adil, keluwesan dalam pendekatan pembelajaran, dan hasil 


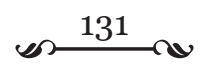

belajar peserta didik yang baik (Wotruba dan Wright dalam HR, 2015: 6-7).

\section{Pembelajaran Bahasa Inggris yang Efektif}

Seperti yang sudah dijelaskan dalam sub bab sebelumnya tentang pembelajaran yang efektif maka hakikat pembelajaran Bahasa Inggris yang efektif adalah suatu proses kegiatan belajar mengajar Bahasa Inggris yang memungkinkan peserta didik dapat belajar bahasa tersebut dengan mudah, menyenangkan, dan dapat tercapai tujuan pembelajaran yang telah ditetapkan.

Pengaplikasian pembelajaran Bahasa Inggris yang efektif di Indonesia sangat diperlukan mengingat Bahasa Inggris merupakan bahasa asing bagi orang Indonesia. Posisi bahasa Inggris sebagai bahasa asing yang berlaku di Indonesia seperti yang diungkapkan oleh seorang ahli yang mengatakan "Jika dibeberapa negara ASEAN, Malaysia dan Brunai Darusalam dan Philipina bahasa Inggris berkedudukan sebagai bahasa kedua (second language), di Indonesia, posisi bahasa Inggris adalah sebagai bahasa asing (Nurhayati, 2009: 3).

Dari kutipan tersebut dapat ditarik kesimpulan bahwa posisi bahasa Inggris sebagai bahasa asing merupakan bahasa yang tidak digunakan untuk berkomunikasi dalam kehidupan sehari-hari melainkan hanya efektif digunakan di dalam kelas sehingga kosa kata bahasa Inggris yang dikuasai para siswa di Indonesia terbatas. Mempertimbangkan posisi Bahasa Inggris sebagai bahasa asing yang hanya efektif digunakan di kelas, seorang guru Bahasa Inggris harus mampu menciptakan suasana dimana para siswa tertarik untuk belajar bahasa tersebut.

Berbagai cara bisa dilakukan untuk menciptakan suasana belajar dan mengajar Bahasa Inggris yang efektif dengan suasana yang menyenangkan. Salah satunya dengan penggunaan media belajar yang bisa ditemukan di lingkungan sekitar seperti foto, gambar, realia, video, lagu dan lain-lain. Selain itu, diharapkan guru Bahasa Inggris berperan menjadi 1. Kreator yang mengkreasi metode, cara proses pembelajaran, 2. Motivator yang memotivasi para siswa agar belajar, 3. Moderator atau fasilitator para siswanya dalam belajar, 4 . Resource yang menjadi sumber dan tempat bertanya bagi para siswanya dan 5 . Leader yang memimpin para siswanya dalam proses pembelajaran (Utami, 2013: 13). 


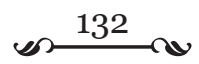

Dari penggunaan cara-cara tersebut diharapkan bisa memotivasi para siswa untuk belajar bahasa Inggris. Mempertimbangkan peranan Bahasa Inggris yang begitu penting dalam dunia international yakni sebagai bahasa yang menjembatani masyarakat international maka sangat diharapkan orang-orang di Indonesia bisa menguasai bahasa Inggris dengan tepat dan lancar.

\section{Konsep Pembelajaran Bahasa Inggris untuk Anak Sekolah Dasar}

Bahasa Inggris adalah bahasa international yang digunakan sebagai alat komunikasi antar negara. Maka dari itu, diharapkan orang Indonesia mampu menguasai bahasa tersebut dengan baik dan lancar. Mempertimbangkan pentingnya bahasa Inggris, maka mata pelajaran Bahasa Inggris diajarkan di setiap lembaga-lembaga pendidikan formal mulai dari tingkat sekolah dasar sampai perguruan tinggi di Indonesia.

Ada beberapa alasan pengajaran Bahasa Inggris di tingkat sekolah dasar yaitu memperkenalkan kepada anak-anak sejak dini dalam memahami budaya asing sehingga tumbuh sikap toleransi dan simpatik, alat berkomunikasi dalam memahami konsep-konsep baru, waktu belajar yang maksimal, tidak membutuhkan banyak waktu untuk dapat menguasainya, dapat digunakan sebagai media pembelajaran (Brumfit dalam Zulkifli, 2014: 180).

Namun demikian, ada hal-hal khusus yang perlu diperhatikan oleh guru bahasa Inggris dalam mengajarkan bahasa tersebut ke anak-anak tingkat sekolah dasar yaitu

1. Kosakata yang terbatas. Jangan bergantung pada kata yang diucapkan saja.

2. Bermain dengan bahasa. Melalui kegiatan yang menyenangkan seperti bermain, anak-anak memiliki kemampuan yang besar untuk menyerap bahasa.

3. Keanekaragaman kelas. Karena konsentrasi dan perhatian dari anak-anak yang rendah, maka suatu keharusan bagi seorang guru membuat keanekaragaman, baik itu berupa kegiatan, kecepatan, organisasi, media, atau yang lain.

4. Rutinitas. Anak-anak jadi tau akan peraturan dan situasi.

5. Kerjasama. Kebanyakan anak ingin berbagi dengan anak-anak lain 


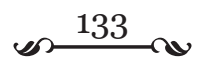

di sekitar mereka, dan duduk dengan orang lain untuk bekerjasama (Scott dan Ytreberg dalam Zulkifli, 2014: 180).

Dari penjelasan di atas dapat ditarik kesimpulan bahwa mengajar Bahasa Inggris untuk siswa level sekolah dasar berbeda dengan level SMP, SMA ataupun universitas. Mengajar bahasa Inggris untuk siswa SD tidak sekedar diartikan hanya menyampaikan materi kepada siswa dan siswa mendengarkan. Jika hal itu dilakukan, anak akan merasa bosan dan cenderung tidak memperhatikan penjelasan dari guru. Hendaknya, guru harus lebih kreatif dalam mengelola kelas seperti mengajar dengan cara yang menyenangkan dengan memanfaatkan media yang bisa ditemukan di lingkungan sekitar baik berupa lagu, realia, video, dsb ataupun melakukan variasi dalam segi kegiatan pengajaran misalnya menggunakan teknik pengajaran yang menarik sehingga memungkinkan anak-anak memperhatikan guru dan termotivasi untuk belajar bahasa Inggris dengan sendirinya.

Selain itu, guru yang mengajar siswa sekolah dasar harus memperhatikan karakter anak sekolah dasar yang umumnya dibagi menjadi 2 kelompok.

Pertama adalah usia 5-7 tahun. Kelompok kedua adalah 8-10 tahun. Karakteristik kelompok pertama, yaitu berbicara tentang apa yang mereka lakukan, memberitahu anda tentang apa yang telah mereka lakukan atau mendengar, kegiatan perencanaan, menggunakan logika penalaran, dan interaksi manusia secara langsung pemahaman. Karakteristik dari kelompok kedua, yaitu mengatakan perbedaan antara fakta dan fiksi, meminta pertanyaan sepanjang waktu, membuat beberapa keputusan tentang pembelajaran mereka sendiri, memiliki pandangan yang pasti tentang apa yang mereka suka dan tidak suka lakukan Scott dan Ytreberg dalam Zulkifli, 2014: 179)

Dari masing-masing karakteristik, kita dapat menarik kesimpulan bahwa di dalam kelas bahasa asing, yang kelompok kedua lebih siap dan memiliki kesadaran bahasa yang lebih daripada yang pertama. Maka dari itu, seorang guru bahasa asing dalam hal ini bahasa Inggris hendaknya harus mengetahui karakterik anak didiknya yang hendak diajar sehingga 


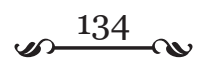

bisa menyesuaikan model pembelajaran seperti apa, media, sistem pengelolaan kelas, dsb.

\section{Pentingnya Penggunaan Lagu dalam Pembelajaran Bahasa Inggris untuk Anak Sekolah Dasar}

Media pembelajaran adalah segala sesuatu yang digunakan untuk menyalurkan pesan serta dapat merangsang pikiran, perasaan, perhatian, dan kemauan si pelajar sehingga dapat mendorong terjadinya proses belajar (Miarso dalam Miranti, Engliana, dan Hapsari, 2014: 169). Dengan kata lain media pembelajaran dapat memotivasi siswa untuk ikut berpartisipasi aktif dan tertarik untuk mengikuti kegiatan belajar mengajar dengan baik. Dalam hal ini, media pembelajaran memiliki dua peranan penting yaitu

1. Media sebagai alat bantu dalam proses pembelajaran, media digunakan untuk menjelaskan bahan ajar agar mudah dipahami siswa sehingga tujuan pembelajaran mampu tercapai.

2. Media sebagai sumber belajar yaitu sebagai sumber materi yang digunakan didalam proses pembelajaran.

Ada berbagai macam media pembelajaran yang bisa dimanfaatkan untuk mendukung kegiatan belajar dan mengajar misalnya lagu, video, gambar, foto, realia, kaset, CD dll. Dalam hal ini media pembelajaran dibagi menjadi 6 jenis yaitu teks, media audio, media visual, media proyeksi gerak,benda-benda tiruan/miniature dan manusia termasuk di dalamnya guru, siswa, atau pakar/ahli di bidang/materi tertentu (Heinich dan Molenda dalam Miranti, Engliana, dan Hapsari, 2014: 169).

Berdasarkan penjelasan di atas ada 6 jenis media yang bisa dimanfaatkan untuk kegiatan belajar mengajar. Dalam konteks pembelajaran bahasa Inggris untuk anak tingkat sekolah dasar, lagu (media audio) dianggap sebagai media yang efektif yang bisa digunakan untuk merangsang keaktifan para peserta didik selama kegiatan belajar dan mengajar berlangsung. Hakekat lagu itu sendiri berarti sekumpulan kata-kata yang dinyanyikan dan diiringi dengan menggunakan alat musik tertentu. Senada dengan hal tersebut seorang ahli mengemukakan pendapatnya tentang lagu sebagai karya musikal pendek, dengan teks yang puitis, yang sama-sama pentingnya antara musik dan kata- kata. Karya itu 


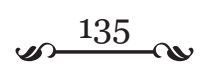

bisa tertulis, beberapa dalam bentuk suara dan biasanya dibarengi dengan instrumen (Encyclopedia dalam Ifadah dan Aimah, 2012: 365).

......lagu merupakan bagian yang penting dari pembelajaran bahasa Inggris karena lagu menjadikan para siswa lebih sensitif terhadap bunyi, dan mempelajari bahasa Inggris tidak lain adalah mempelajari berbagai jenis bunyi yang bermakna. Lagu juga bisa menjadikan kelas lebih menarik dan semarak. Saat anak menyukai lagu yang diajarkan guru, mereka akan dengan senang hati dan antusias melakukannya. Dan saat itulah, secara tidak langsung mereka tengah mempelajari sesuatu (Sophya, 2013: 8).

Dari kutipan diatas, dapat diambil kesimpulan bahwa ada beberapa alasan mengapa lagu dianggap menjadi media yang cukup efektif untuk mengajar bahasa Inggris bagi siswa sekolah dasar. Selain itu, perlu disadari para sasaran pengajaran Bahasa Inggris adalah anak SD di Indonesia yang mana bahasa Inggris menjadi bahasa asing, sehingga pemilihan media lagu bahasa Inggris yang sesuai bisa menciptakan suasana belajar yang menyenangkan (joyful learning). Lebih dari itu, kata-kata yang digunakan dalam lagu cenderung lebih simple sehingga memudahkan para siswa SD di Indonesia untuk mempelajari bahasa Inggris dengan mudah.

Beberapa keuntungan mengajarkan bahasa Inggris menggunakan nyanyian adalah sebagai berikut:

1. Melalui lagu akan memotivasi anak untuk lebih senang mempelajari bahasa Inggris.

2. Dengan menyanyi anak menjadi senang dan lebih mudah dalam memahami materi ajar yang disampaikan. Kemampuan guru dalam memilih lagu dan menciptakan gerakan yang sesuai dengan usia perkembangan anak akan berdampak pula terhadap berhasilnya proses pembelajaran bahasa Inggris pada anak usia dini.

3. Melalui nyanyian dan kegiatan pembelajaran yang bervariasi, pendidik dapat menumbuhkan minat anak untuk lebih senang dan giat belajar, bahkan dapat memudahkan anak dalam memahami materi ajar yang disampaikan.

4. Anak dibuat senang, tidak bosan, dan tertarik dalam mengikuti 


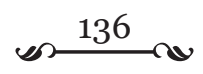

proses pembelajaran. Dengan demikian bernyanyi merupakan suatu kegiatan yang sangat disukai oleh anak- anak. (Miranti, Engliana dan Hapsari, 2015: 169)

Mempertimbangkan hal di atas maka, media lagu dianggap memiliki banyak sisi positif yang bisa dimanfaatkan untuk pembelajaran bahasa Inggris pada umunya dan untuk tingkat sekolah dasar pada khususnya.

\section{Konsep Pengajaran Lagu Bahasa Inggris untuk Anak Sekolah Dasar}

Ada beberapa macam lagu bahasa Inggris yang biasa dinyanyikan di tingkat sekolah dasar seperti ABC, Ten Little Fingers, Ten Little Indians, Old Mc Donald, Bingo, That is, Days of the Week, Moths, I have A Cock, Wheel on the Bus, The Bear Went Over the Mountain, Can You Touch Your Toes, London Bridge, Head and Shoulders, Twinkle Twinkle Little Stars, Bluebird, Are You Sleeping, If you are happy?, A hundred Miles dsb. Dalam hal ini, lagu-lagu Bahasa Inggris dikategorikan menjadi beberapa jenis seperti activity song, animal song, counting song, food song, learning song, lullaby, patriotic song, parody, sport song, traditional song, dan sebagainya. Untuk kebutuhan pengajaran bahasa Inggris untuk anak tingkat sekolah dasar hendaknya seorang guru bahasa Inggris melakukan pemilihan lagu yang tepat.

Seorang peneliti lagu menyatakan bahwa sebelum menggunakan lagu sebagai media pengajaran untuk anak SD hendaknya guru memilih lagu yang sederhana dan sesuai dengan kebutuhan belajar. Pilih pula lagu yang liriknya bisa terdengar jelas, juga pelafalan (pronunciation) yang benar. Karena siswa akan menggunakan lagu sebagai model maka tentu mereka harus menemukan model yang terbaik. Jika guru yang akan menyanyikannya, maka harus dipastikan pula bahwa sang guru tersebut akan memberi model yang baik bagi siswanya (Nurhayati, 2009: 65).

Berikut ini adalah contoh langkah-langkah pembelajaran bahasa Inggris dengan menggunakan lagu:

1. Memperkenalkan lagu kepada anak hendaknya diawali dengan penjelasan awal tentang tema lagu bahasa Inggris yang akan dinyanyikan.

2. Lagu dinyanyikan oleh guru untuk pertama kalinya dan meminta 


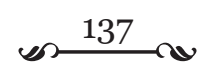

anak utuk mendengarkannya.

3. Siswa diminta untuk menyanyikan lagu bersama guru dengan irama ataupun tempo yang lambat.

4. Guru dan siswa mengartikan lagu ke dalam bahasa Indonesia yang benar

5. Guru dan siswa menyanyikan lagu bersama-sama berulang kali mulai dari tempo yang lambat perlahan-lahan sampai pada irama ataupun tempo yang sebenarnya.

6. Guru menunjuk siswa secara berkelompok ataupun secara sendirisendiri untuk menyanyikan lagu bahasa Inggris di depan kelas (Suprijono dalam Suleman, 2013: 9).

Ada beberapa hal yang perlu diperhatikan dalam penggunaan lagu sebagai media pembelajaran bahasa Inggris yaitu lagu yang diajarkan memiliki tempo yang lambat. Sebaliknya apabila temponya cepat hendaknya diulangi beberapa kali dengan diawali dengan tempo yang agak lambat dari lagu yang sebernarnya dan disesuaikan dengan tingkat penguasaan anak, pengucapan, irama yang mudah dan mengarah pada tujuan pembelajaran bahasa bagi anak Sekolah Dasar. Setelah selesai menyanyikan lagu bahasa Inggris bersama-sama, siswa diberi latihan dengan cara melengkapi lirik lagu yang belum lengkap sehingga bisa melatih ketajaman memori mereka dalam mengingat lagu bahasa asing.

Dalam hal ini pengajaran menggunakan lagu dapat meningkatkan 4 ketrampilan bahasa yaitu listening (mendengarkan) ketika lagu dinyanyikan oleh guru untuk pertama kalinya dan meminta anak untuk mendengarkannya, speaking (berbicara) ketika siswa diminta untuk menyanyikan lagu bersama guru, reading (membaca) ketika guru dan siswa mengartikan lagu ke dalam bahasa Indonesia yang benar. Ini berarti sebelum mengartikan lirik dalam bahasa Indonesia, siswa membaca lirik dalam bahasa Inggris. Writing (menulis) ketika siswa diberi latihan dengan cara melengkapi lirik lagu yang belum lengkap sehingga bisa melatih ketajaman memori mereka dalam mengingat lagu bahasa asing.

\section{Siswa Madrasah Ibtidaiyah}

Kata madrasah berasal dari Bahasa Arab yaitu "madrasah" yang berarti "tempat belajar". Tempat belajar diartikan sekolah. Dalam hal ini 


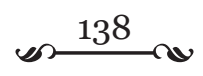

madrasah dan sekolah sebagai tempat menuntut ilmu memiliki sedikit perbedaan. Perbedaannya adalah sekolah dikenal sebagai lembaga pendidikan tingkat dasar dan menengah yang kurikulumnya lebih menitikberatkan pada pelajaran umum dan pengelolaannya berada dibawah naungan departemen pendidikan nasional sedangkan madrasah dikenal sebagai lembaga pendidikan keagamaan tingkat dasar dan menengah yang lebih menitiberatkan pada mata pelajaran agama dan dibawah naungan Departemen agama.

Membahas tentang madrasah, pada awalnya madrasah dibagi menjadi 2 jenis yaitu madrasah diniyah dan non-diniyah. Madrasah diniyah memberikan 100\% pendidikan agama sedangkan non-diniyah memberikan pendidikan agama dan umum. Seiring dengan perkembangan zaman madrasah non diniyah dipandang sebagai sekolah umum berciri khas Islam, atau dapat dikatakan "sekolah plus". Madrasah atau sekolah umum berciri khas Islam dibagi menjadi 2 jenis yaitu madrasah swasta dan madrasah negeri. Penegrian dilakukan oleh pemerintah. Penegerian pertama dilakukan pada madrasah tingkat pemula (ibtidaiyah) melalui sejumlah keputusan/ketetapan Menteri Agama berikut;

1. Ketetapan Menteri Agama Nomor 1/1959;

2. Keputusan Menteri Agama Nomor 2/1959

Madrasah menurut levelnya dibagi menjadi tiga yaitu Madrasah Ibtidaiyah, setingkat dengan Sekolah Dasar; Madrasah Tsanawiyah, setingkat dengan Sekolah Menengah Pertama; dan Madrasah Aliyah, setingkat dengan Sekolah Menengah Atas. Membahas tentang madrasah ibtidaiyah yaitu sekolah islam yang setara dengan sekolah dasar, mata pelajaran yang diajarkan di madrasah ibtidaiyah memberikan pendidikan agama 30\% dan umum 70\% kepada peserta didik. Ini berarti siswa madrasah ibtidaiyah tidak hanya diberi mata pelajaran umum tetapi juga mata pelajaran agama. Pendidikan agama diberikan melalui mata pelajaran Al-Qur'an Hadits, Aqidah-Akhlak, Fiqih, SKI, Bahasa Arab sedangkan mata pelajaran umum melalui mata pelajaran Pendidikan Pancasila dan Kewarganegaraan, Bahasa Indonesia, Matematika, Ilmu Pengetahuan Alam, Ilmu Pengetahuan Sosial, Kerajinan Tangan dan Kesenian, Pendidikan Jasmani dan Kesehatan, Muatan Lokal (Bahasa Inggris).

Misi yang ingin dicapai di madrasah ibtidaiyah umumnya berupaya 


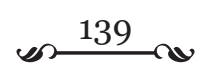

menggali dan mengembangkan seluruh potensi dan dimensi baik personal, agama, susila dan sosial yang dimiliki peserta didik. Melalui usaha ini memungkinkan setiap peserta didik, tanpa kecuali, dapat mendorong tumbuhnya nilai-nilai kejujuran, keadilan, kasih sayang, toleransi, keindahan, dan tanggung jawab dalam pemahaman nilai sesuai tingkat perkembangan dan kemampuan mereka. Dengan kata lain di madrasah ibtidaiyah yang setara dengan sekolah dasar, para peserta didik diberi pengetahuan tentang pendidikan karakter secara komprehensif.

Pendidikankaraktersangatpenting diterapkan demimengembalikan karakter bangsa Indonesia yang sudah mulai luntur karena terpengaruh budaya dari Negara lain yang tidak sesuai dengan budaya bangsa kita. Dengan dilaksanakannya pendidikan karakter di madrasah ibtidaiyah, diharapkan peserta didik memiliki karakter yang baik ketika bergaul baik di lingkungan keluarga, sekolah, maupun masyarakat. Ada beberapa prinsip pendidikan karakter yang efektif (Patimah, 2012: 35-37) yaitu madrasah Ibtidaiyah mengembangkan dan meningkatkan nilai-nilai inti etika dan kinerja sebagai landasan karakter yang baik, madrasah Ibtidaiyah berusaha mendefinisikan "karakter" secara komprehensif, didalamnya mencakup berpikir, merasa, dan melakukan dan madrasah Ibtidaiyah menggunakan pendekatan yang komprehensif, intensif, dan proaktif dalam pengembangan karakter. Pendidikan karakter dimaksudkan untuk membentuk sosok manusia yang kuat dan tidak mudah goyah dalam menghadapi segala permasalahan yang ada.

\section{Lagu Anak-Anak yang Efektif untuk Pembelajaran Bahasa Inggris bagi Siswa Madrasah Ibtidaiyah}

Bahasa asing adalah bahasa yang yang tidak digunakan sebagai alat komunikasi di negara tertentu di mana bahasa tersebut diajarkan. Sementara bahasa kedua adalah bahasa yang bukan bahasa utama namun menjadi salah satu bahasa yang digunakan secara umum di suatu negara (Miranti, Engliana, dan Hapsari, 2015: 167). Karena posisi bahasa Inggris di Indonesia sebagai bahasa asing sehingga orang-orang di Indonesia tidak menggunakannya dalam komunikasi sehari-hari dan hanya efektif digunakan didalam kelas saja ketika kegiatan belajar mengajar berlangsung, maka diperlukan suatu strategi pembelajaran yang efektif.

Arti pembelajaran efektif adalah suatu pembelajaran yang 


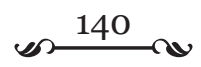

memungkinkan peserta didik untuk dapat belajar dengan mudah, menyenangkan, dan dapat tercapai tujuan pembelajaran yang telah ditetapkan (HR, 2015: 6). Karakteristik anak-anak adalah butuh bergerak, bisa berkonsentrasi untuk masa yang pendek, belajar melalui pengalaman, belum begitu mampu mengontrol dan merencanakan kegiatannya, tidak takut melakukan kesalahan atau mengambil resiko, tidak begitu memperhatikan diri mereka sendiri ataupun tindakan mereka, memperhatikan makna bahasa dan memiliki pengalaman yang terbatas dalam kehidupannya (Ellie dalam Nurhayati, 2009: 66). Oleh karena itu, pemilihan media penunjang pembelajaran yang tepat sangat diharapkan demi tercapai tujuan pembelajaran. Salah satunya adalah penggunaan lagu sebagai media pembelajaran. Hakekat lagu itu sendiri berarti sekumpulan kata-kata yang dinyanyikan dan diiringi dengan menggunakan alat musik tertentu. Karya itu bisa tertulis, beberapa dalam bentuk suara dan biasanya dibarengi dengan instrumen (Encyclopedia dalam Ifadah dan Aimah, 2012: 365). Manfaat dari penggunaan lagu sebagai media pembelajaran bagi siswa sekolah dasar atau madrasah ibtidaiyah diakui oleh beberapa peneliti. Dua diantaranya menyatakan bahwa

Lagu merupakan "alat" yang sangat baik untuk membantu proses belajar bahasa Inggris siswa, lebih khusus lagi lagu diyakini mampu memotivasi siswa selama mengikuti pembelajaran bahasa Inggris. Dapat pula dikatakan bahwa lagu merupakan bagian yang penting dari pembelajaran bahasa Inggris karena lagu menjadikan para siswa lebih sensitif terhadap bunyi, dan mempelajari bahasa Inggris tidak lain adalah mempelajari berbagai jenis bunyi yang bermakna. Lagu juga bisa menjadikan kelas lebih menarik dan semarak. Saat anak menyukai lagu yang diajarkan guru, mereka akan dengan senang hati dan antusias melakukannya. Dan saat itulah, secara tidak langsung mereka tengah mempelajari sesuatu (Nurhayati, 2009: 66 dan Sophya, 2013: 8).

Menurut jurnal yang dibuat oleh Lusi Nurhayati (2009) dan Ida Vera Sophya (2013) yang menjadi sumber data dalam penelitian ini tentang pembelajaran bahasa Inggris dengan memanfaatkan media lagu anakanak bagi siswa sekolah dasar menunjukkan bahwa ada 20 lagu anakanak yang bisa digunakan untuk media pembelajaran bagi siswa sekolah dasar atau madrasah ibtidaiyah. 20 lagu tersebut berjudul "If you're happy 


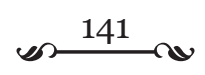

and you know it, Hokey Pokey", 10 little Indians, The Wheels on the Bus, There was an old lady who swallow a fly, London Bridge is Falling Down, Head, Shoulders, Knees and Toes, Twinkle twinkle little stars, Old Mc Donald had a farm, Good morning 2x, ABC, Bingo, Months, Days of the Week, I have a Cock, That is, Can You TouchYour Toes, Are you Sleeping / Studying, My Eyes, My Ears, My nose, My mouth, The Bear Went Over The Mountain.

Lagu-lagu tersebut efektif digunakan dalam pembelajaran bahasa Inggris bagi siswa madrasah ibtidaiyah yang setara dengan sekolah dasar karena ke 20 lagu tersebut sesuai dengan prinsip penggunaan lagu bahasa Inggris anak-anak bagi siswa tingkat sekolah dasar/MI yakni (1) sesuai dengan tingkat kemampuan siswa SD/ madrasah ibtidaiyah. Anak-anak MI berada dalam masa keemasan sehingga mereka lebih mahir dalam menyerap hal-hal baru termasuk belajar bahasa Inggris. (2) jenis lagunya sesuai untuk anak level sekolah dasar atau madrasah ibtidaiyah misalnya pronunciationnya bagus dan mudah diucapkan kosakatanya (3) lagulagu tersebut memiliki tingkat kesulitan yang tidak terlalu tinggi karena Pembelajaran Bahasa Inggris khususnya pada anak usia sekolah dasar, lebih menekankan pada pengenalan akan perintah-perintah dasar (Basic Instructions) dan pengetahuan akan nama-nama benda atau objek yang ada di sekitar mereka (Vocabulary).

Selain itu, lagu-lagu tersebut memenuhi salah satu prinsip pembelajaran yaitu automaticity (secara otomatis). Menurutnya, faktor yang cenderung menghambat kemunculan automaticity ini adalah terlalu berlebihan dalam menganalisa bahasa, berfikir terlalu banyak tentang forms (struktur/grammar) dan secara sadar mengingat-ingat aturan bahasa (Brown, 2000: 167). Dalam hal ini lagu-lagu tersebut bisa membantu terjadinya automatic processing of language dimana siswa mengerjakan sebuah kegiatan belajar tanpa sengaja.

\section{Keuntungan Penggunaan Lagu Anak-Anak untuk Pembelajaran Bahasa Inggris bagi Siswa Madrasah Ibtidaiyah}

Posisi bahasa Inggris di Indonesia adalah sebagai bahasa asing. Itu berarti bahasa yang tidak digunakan untuk komunikasi sehari-hari melainkan efektif digunakan untuk berkomunikasi dalam kelas saja sehingga seringkali ditemukan kendala yang ditemukan di lapangan dalam 


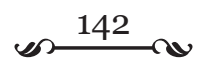

pembelajaran bahasa Inggris di Indonesia apalagi jika sasaran peserta didik adalah anak sekolah dasar yang memiliki karakter yang berbeda dengan pengajaran anak SMP ke atas. Oleh karena itu, penggunaan media pembelajaran yang tepat sangatlah diperlukan demi meningkatkan motivasi siswa untuk mempelajari bahasa tersebut. Salah satu media pembelajaran yang dipandang efektif digunakan adalah lagu.

Lagu berasal dari sebuah karya tertulis yang diperdengarkan dengan iringan musik. Penggunaan lagu banyak digunakan oleh guru karena lagu dipandang efektif sebagai media pembelajaran. Hal ini disebabkan karena orang-orang yang mendengarkan lagu bisa merasa sedih, senang, bersemangat dan perasaan emosi lain karena efek dari lagu yang begitu menyentuh. Selain itu, lagu mampu menyediakan sarana ucapan yang secara tidak sadar disimpan dalam memori di otak. Keadaan inilah yang justru dianggap bagus karena pembelajaran tidak terasa kaku atau tidak terkesan dikondisikan. Dengan kata lain pembelajaran bisa berlangsung dengan efektif dan terjadi secara alamiah. Efektifitas penggunaan lagu anak-anak berbahasa Inggris juga dibuktikan oleh 2 orang peneliti dalam jurnalnya yang berjudul"Penggunaan Lagu dalam Pembelajaran Bahasa Inggris untuk Siswa SD; Mengapa dan Bagaimana” oleh Lusi Nurhayati dan "Pembelajaran Bahasa Inggris melalui Lagu pada Anak Usia Dini" oleh Ida Vera Sophya. 2 jurnal tersebut menjadi sumber data sekunder yang dianalisis oleh penulis.

Berdasarkan hasil penelitian dalam jurnal yang ditulis oleh Lusi Nurhayati dan Ida Vera Sophya yang dianalisis oleh penulis berkaitan dengan keuntungan penggunaan lagu anak-anak untuk pembelajaran bahasa inggris bagi siswa madrasah ibtidaiyah menunjukkan bahwa penggunaan lagu anak-anak sebagai media pembelajaran bahasa Inggris sangatlah bermanfaat. Dalam pembahasan hasil penelitian yang dilakukan oleh Lusi Nurhayati, beliau mengungkapkan bahwa lagu merupakan 'alat' yang sangat baik untuk membantu proses belajar bahasa Inggris siswa, lebih khusus lagi lagu diyakini mampu memotivasi siswa selama mengikuti pembelajaran bahasa Inggris. Dapat pula dikatakan bahwa lagu merupakan bagian yang penting dari pembelajaran bahasa Inggris karena lagu menjadikan para siswa lebih sensitif terhadap bunyi, dan mempelajari bahasa tidak lain adalah mempelajari berbagai jenis bunyi yang bermakna. Lagu menjadikan kelas lebih menarik dan semarak. Saat 


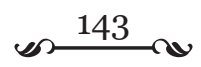

anak menyukai lagu yang diajarkan guru, mereka akan dengan senang hati dan antusias melakukannya. Dan saat itulah, secara tidak langsung mereka tengah mempelajari sesuatu (Nurhayati, 2009: 66-67).

Sedangkan pembahasan dari hasil penelitian yang dilakukan oleh Ida Vera Sophya (2013) tentang penggunaan lagu untuk media pembelajaran bahasa Inggris juga menunjukkan hasil yang sama dengan penelitian yang dilakukan oleh Lusi Nurhayati (2009) yakni lagu bermanfaat untuk pembelajaran bahasa Inggris karena lagu bisa meningkatkan motivasi siswa untuk belajar bahasa asing dan dengan lagu anak-anak berbahasa Inggris para siswa belajar bahasa Inggris secara otomatis. Dalam pembahasan hasil jurnal yang dilakukan oleh Ida Vera Sophya (2013), beliau mengemukakan bahwa lagu merupakan suatu kegiatan yang sangat disukai oleh anak-anak. Secara umum menyanyi bagi anak lebih berfungsi sebagai aktivitas bermain daripada aktivitas pembelajaran atau penyampaian pesan. Menyanyi dapat memberikan kepuasan, kegembiraan, dan kebahagiaan bagi anak sehingga mereka dapat mempelajari, menguasai, mendorong anak agar belajar lebih giat (Joyful Learning). Dengan nyanyian lagu, seorang anak akan lebih cepat, dan mempraktikkan suatu materi ajar yang disampaikan oleh pendidik. Selain itu, kemampuan anak dalam mendengar (listening), bernyanyi (singing), berkreativitas (creative) dapat dilatih melalui kegiatan ini.

Dari pembahasan hasil penelitian yang dilakukan oleh 2 peneliti sebelumnya dapat disimpulkan bahawa lagu sangat efektifdigunakan untuk pembelajaran bahasa Inggris di Indonesia terlebih bagi siswa madrasah ibtidaiyah yang setingkat dengan siswa sekolah dasar. Para siswa tersebut membutuhkan teknik khusus (lagu) dalam rangka meningkatkan motivasi mereka dalam belajar bahasa Inggris supaya suasana pembelajaran terasa mudah, menyenangkan dan tujuan pembelajaran tercapai. Berdasarkan hasil analisis penulis terhadap kedua jurnal yang ditulis oleh Lusi Nurhayati dan Ida Vera Sophya tentang pembelajaran bahasa Inggris melalui lagu anak-anak untuk siswa sekolah dasar menunjukkan bahwa penggunaan lagu anak-anak sangatlah efektif dalam pembelajaran bahasa Inggris bagi siswa madrasah ibtidaiyah yang setingkat dengan siswa sekolah dasar. Hal ini berarti sesuai dengan keuntungan penggunaan lagu yang ditulis oleh Brewster dkk (2002).

Pertama, lagu merupakan linguistic resource. Dalam hal ini 
lagu mejadi media pengenalan bahasa baru, sekaligus media untuk penguatan tata bahasa dan kosakata. Lagu bisa dimanfaatkan untuk mengembangkan semua keterampilan bahasa secara integratif, termasuk meningkatkan kemampuan pronunciation siswa. Kedua, lagu merupakan affective/psychological resource. Selain menyenangkan, lagu juga mampu memotivasi siswa sekakigus memupuk attitude yang positif terhadap bahasa Inggris. Ketiga, lagu merupakan cognitive resource. Lagu membantu meningkatkan daya ingat, konsentrasi juga koordinasi. Siswa menjadi lebih sensitif terhadap tanda rima sebagai alat bantu untuk memaknai makna. Keempat lagu bisa menjadi culture resource dan social resource (Brewster dkk, 2002: 162).

\section{Langkah-Langkah Efektif dalam Menggunakan Lagu Anak- Anak untuk Pembelajaran Bahasa Inggris bagi Siswa Madrasah Ibtidaiyah}

Penggunaan lagu sebagai media pembelajaran memiliki langkah langkah tertentu dalam rangka pengaplikasiaanya dalam kegiatan belajar mengajar. Penerapan langkah -langkah penggunaan lagu yang tidak sesuai sebagai media pembelajaran akan menyebabkan tujuan pembelajaran tidak tercapai secara maksimal. Maka dari itu, dalam rangka penggunaan lagu untuk media pembelajaran perlu diperhatikan faktor-faktor seperti guru harus mempertimbangkan beberapa aspek yakni jenis lagu, jumlah siswa, tipe kegiatan pembelajaran dengan lagu, dan karakter siswa, apalagi untuk mengajar anak setingkat sekolah dasar seperti madrasah ibtidaiyah. Karakteristik anak-anak adalah butuh bergerak, bisa berkonsentrasi untuk masa yang pendek, belajar melalui pengalaman, belum begitu mampu mengontrol dan merencanakan kegiatannya, tidak takut melakukan kesalahan atau mengambil resiko, tidak begitu memperhatikan diri mereka sendiri ataupun tindakan mereka, memperhatikan makna bahasa dan memiliki pengalaman yang terbatas dalam kehidupannya (Ellie dalam Nurhayati, 2009: 66).

Berikut ini adalah simpulan langkah-langkah penggunaan lagu anak-anak yang efektif untuk pembelajaran Bahasa Inggris bagi siswa Madrasah Ibtidaiyah berdasarkan hasil penelitian terdahulu dari 2 peneliti (Lusi Nurhayati, 2009 dan Ida Vera Sophya, 2013) yang menjadi data dalam penelitian ini. 


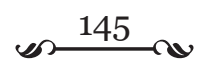

1. Buatlah konteks, dalam hal ini guru perlu menjelaskan tujuan serta latar belakang informasi.

2. Ajarkan terlebih dahulu kosakata yang dianggap penting dengan menggunakan alat bantu visual, aksi/gerakan, realia atau benda tiruan, boneka, dan sebagainya.

3. Perdengarkan kaset atau nyanyikan lagu sehingga siswa bisa menyimak, menunjukan kefahaman mereka dan mulai akrab dengan irama dan nada.

4. Lakukan kegiatan listening lanjutan

5. Perhatikan pronunciation misalnya mengidentifikasi pola intonasi, kata atau silabel yang diberi tekanan (stressed words or syllables).

6. Ajak siswa untuk menyimak, mengulangi, dan berlatih menyanyikan dan belajar lagu tersebut.Beri semangat agar mereka menggunakan gerakan tubuh, ekspresi muka dan sebagainya.

7. Beri catatan tertulis teks lagu.Terkait dengan hal ini guru tidak lantas harus memberikan catatan lengkap lagu yang diajarkannya. Guru bisa mengemasnya ke dalam aktivitas menarik dan berorientasi pembelajaran.

8. Ajak siswa untuk membandingkannya dengan tipe yang sejenis di bahasa ibu mereka, ataupun bahasa nasional.

9. Menampilkannya baik secara bersama, individu, kelompok, berpasangan.

\section{Simpulan}

Kesimpulan dari penelitian ini adalah ada 20 contoh lagu anakanak yang efektif untuk pembelajaran bahasa Inggris bagi siswa Madrasah Ibtidaiyah. Ke 20 lagu tersebut adalah "If you're happy and you know it, Hokey Pokey", 10 little Indians, The Wheels on the Bus, There was an old lady who swallow a fly, London Bridge is Falling Down, Head, Shoulders, Knees and Toes, Twinkle twinkle little stars, Old Mc Donald had a farm, Good morning 2x, ABC, Bingo, Months, Days of the Week, I have a Cock, That is, Can You Touch Your Toes, Are you Sleeping/Studying, My Eyes, My Ears, My nose, My mouth, The Bear Went Over The Mountain. Penggunaan lagu anak-anak untuk pembelajaran Bahasa Inggris menunjukkan bahwa lagu bisa meningkatkan antusias anak-anak untuk belajar bahasa Inggris 


\section{שת 146}

karena pembelajaran yang menyenangkan dan tidak terasa. Maka dari itu, langkah-langkah yang dilakukan untuk menciptakan pembelajaran Bahasa Inggris yang efektif dengan penggunaan lagu anak-anak adalah guru Bahasa Inggris harus mempertimbangkan beberapa aspek yakni jenis lagu, jumlah siswa, tipe kegiatan pembelajaran dengan lagu, dan karakter siswa. Dengan memperhatikan aspek-aspek tersebut, tujuan pembelajaran akan tercapai secara maksimal. 


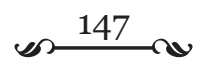 \\ DAFTAR PUSTAKA}

Brewster, J., Ellis, G., Girard, D. 2002. The Primary English Teacher's Guide. England: Penguin English.

Brown, D. 2000. Teching by Principles. Cambridge: CUP.

Hastuti, Erni dan Oswari, Teddy. 2012. Metode Pembelajaran Bahasa Inggris Mandiri dengan Free Virtual Online Course. UG Jurnal, Vol. VI, No 11: $1-7$.

HB, Zulfahmi. 2013. Indikator Pembelajaran Aktif Dalam Konteks Pengimplementasian Pendekatan Pembelajaran Aktif, Kreatif, Efektif, Dan Menyenangkan (Pakem). Jurnal Al-Ta'lim, Vol. 1, No 4: 278-284.

HR, Mansyur. 2015. Menciptakan Pembelajaran Efektif Melalui Apersepsi. Jurnal E-Buletin, Februari 2015, 2355-3189.

Ifadah, Muhimatul dan Aimah, Siti. 2012. Keefektifan Lagu sebagai Media Belajar dalam Pengajaran Pronounciation/Pengucapan. LPPM UNIMUS, Vol. VI, No 11: 363-370.

Miranti, Ira, Engliana, dan Hapsari, Fitri Senny. 2015. Penggunaan Media Lagu Anak-Anak dalam Mengembangkan Kemampuan Kosakata Bahasa Inggris Siswa di Paud. Jurnal Ilmiah Kependidikan, Vol. II, No 2: $167-173$.

Mulyanah. 2014. Efektivitas Pembelajaran Akidah Akhlak pada Siswa Kelas

IV di Madrasah Ibtidaiyah. Skripsi. Jakarta: Fakultas Ilmu Tarbiyah dan Keguruan Universitas Islam Negeri Syarif Hidayatullah.

Nurhayati, Lusi. 2009. Penggunaan Lagu dalam Pembelajaran Bahasa Inggris untuk Siswa SD; Mengapa dan Bagaimana. Jurnal Majalah Ilmiah Pembelajaran, Vol.V, No I: 53-75.

Patimah, 2012. Pendidikan Karakter di Madrasah Ibtidaiyah. Jurnal Penelitian, Vol. IX, No 2: 30-39.

Sophya, Ida Vera. 2013. Pembelajaran Bahasa Inggris melalui Lagu pada Anak Usia Dini. Jurnal Thufula, Vol. 1, No.1: 1-21.

Suleman, Herlina. 2013. Kemampuan Kosakata Bahasa Inggris Menggunakan Lagu pada Siswa Kelas II SDN 15 Kecamatan Tibawa Kabupaten Gorontalo. Skripsi. Gorontalo. Fakultas Ilmu Pendidikan Universitas Gorontalo. 


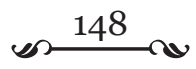

Suyono, 2009. Pembelajaran Efektif dan Produktif Berbasis Literasi: Analisis Konteks, Prinsip, dan Wujud Alternatif Strategi Implementasinya di Sekolah. Jurnal Bahasa dan Seni, Vol. 37, No 2: 203-216.

Utami, Elfa Febria. 2013. Pengelolaan Pembelajaran Bahasa Inggris (Studi Perbandingan antara SMPN 1 dan SMPN 14 Kota Bengkulu). Tesis. Bengkulu. Fakultas Keguruan Ilmu Pendidikan Universitas Bengkulu.

Wahab, Rochmat. 2009. Pembelajaran yang Efektif, Efisien, dan Menarik Sesuai dengan Perkembangan Teknologi Modern. Yogyakarta: AAU Yogyakarta.

Yasin, H. Salehuddin. 2012. Metode Belajar dan Pembelajaran yang Efektif. Jurnal Adabiyah, Vol. XII, No 1: 1-9.

Zulkifli, Nur Aisyah. 2014. Meningkatkan Kemampuan Bahasa Inggris Siswa dengan Menggunakan Running Dictation melalui Materi Agama di SD It Al-Fittiyah Pekanbaru. Jurnal Penelitian Sosial Keagamaan, Vol.17, No 2: 175-197. 